\title{
Health Impact Assessment and its Association with the Environment: an integrative review
}

\author{
Simone Cristine dos Santos Nothaft \\ Nunzia Linzalone \\ Maria Assunta Busato
}

${ }^{1}$ Community University of the Chapecó Region, Chapecó, SC, Brazil

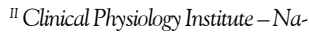
tional Research Council, Pisa, Italy

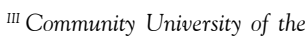
Chapecó Region, Chapecó, SC, Brazil.

\begin{abstract}
To identify and analyze the contents of scientific literature on Health Impact Assessment in relation to the environment. An integrative literature review carried out by searching for studies in the Periodicals Portal of the Coordination for the Improvement of Higher Education Personnel. A total of 38 studies were included; the period with the greatest number of publications was between 2012 and 2014, with studies developed mainly in Europe and North America. The categories that emerged were Health Impact Assessment practice; Health Impact Assessment and Urban Planning; Environmental Impact Assessment and Health Impact Assessment; and Environment and Health. There is a movement for the integration of Health Impact Assessment into Environmental Impact Assessment and the consequent institutionalization of that integration since Environmental Impact Assessment already has a consolidated legal base.
\end{abstract}

Keywords: Environment, urban planning, health, Environmental Impact Assessment.

São Paulo. Vol. 23, 2020

Original Article

DOI: http://dx.doi.org/10.1590/1809-4422asoc20180211r2vu2020L6AO 


\section{Introduction}

The study object of this manuscript is Health Impact Assessment and its association with the environment. According to the Pan-American Health Organisation (PAHO), Health Impact Assessment (HIA) is an approach that seeks to protect and improve human collective and individual health, offering a practical evidence-based tool that enables governments to improve their processes (PAHO, 2013).

In that perspective, with the growth of urban centers worldwide, the need arises to accompany the generation of health impacts in all economic, social and political development contexts. In Brazil, the adoption of structured, standardized health impact methodology, such as the Health Impact Assessment, could reduce the generation of adverse effects on health stemming from public policies that usually fail to consider the medium and long-term prospects (ABE; MIRAGLIA, 2018). What can be seen is that scientific production regarding the practice of Health Impact assessment in Brazil, is merely incipient. Knowledge regarding HIA in Brazil has intensified; the first material produced in the country was the document Health Impact Assessment - HIA: methodology adapted for application in Brazil (Avaliação de Impacto à Saúde - AIS: metodologia adaptada para aplicação no Brasil) (BRASIL, 2014). The publication was designed to publicize the methodology, fostering discussion of it and its application on the part of professionals and institutions in various sectors whose activities and services are liable to cause health impacts. Apart from that guidelines document produced by the Brazilian Ministry of Health, there are very few publications regarding the application of HIA in Latin America as a whole, which suggests that, unlike the situation in the developed countries, the practice and application of HIA is not a common occurrence in the region (ABE; MIRAGLIA, 2018).

Considering how recent this practice is, one of the possibilities that presents itself is to incorporate HIA to Environmental Impact Assessment (EIA) and that could be achieved by integrating Health into the EIA legislation and introducing the proposal in the discussions on changes to the extant Environmental Licensing system. To that end, efforts to insert HIA should be based on fostering discussions of the experiences reported in Brazilian case studies, especially in the health sector and environment sector (HACON et al., 2018). Given that the discussion of HIA addresses its aspect as a practice fostering protection for human health in a systemic context, and considering the contemporary nature of the theme, it is necessary to acquire more knowledge about this approach. With that in mind, this study conducted a review of the literature on Health Impact Assessment and its association with environmental changes.

\section{Methodology}

This study is an integrative review designed to gather and synthesize the results of research into a clearly delimited question and collaborate towards enhancing in-depth knowledge of the respective theme (MENDES; SIVEIRA; GALVÃO, 2008). The integrative review was conducted according to Ganong (1987) and Soares et al. (2014) and consisted of 
the following steps: protocol elaboration with identification of the problem and the objective, data gathering, study screening and selection, critical evaluation of the studies, data analysis, results and manuscript elaboration.

The online search for appropriate studies was carried out in August 2017 in the databases of the Periodicals Portal of the Coordination for the Improvement of Higher Education Personnel (Coordenação de Aperfeiçoamento de Pessoal de Nivel Superior - CAPES). The portal is a virtual library that makes the best international scientific production available to Brazilian teaching and research institutions. Its collection consists of more than 45 thousand titles with unabridged texts, 130 reference bases, and 12 bases exclusively dedicated to patents (BRASIL, 2017). The criteria adopted for inclusion in the study were: articles on the theme in any language; published up until 2017; peer reviewed and accessible; with a discussion of the association between HIA and the environment in the body of the text; or with specific mention of the object of this study in their titles, abstracts or objectives, whether general or specific. The question orientating this study was: what is the scientific production regarding HIA and its association with the environment?

Study selection was made in August 2017 based on an electronic search in the abovementioned portal and subsequent reading of those works that were culled for presenting the terms 'Health Impact Assessment' and 'Environment'. The quantities of articles obtained are displayed schematically in Figure 1.

Figure 1 - Schematic representation of the search in the CAPES Periodicals Portal, showing the search strings and numbers of publications retrieved.

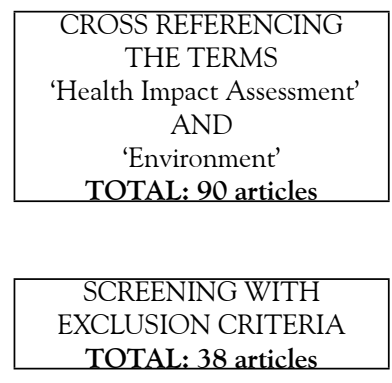

Source: the authors, 2020.

\section{Results}

The results show that the period with the highest number of publications, according to the objective and inclusion criteria of this review, was from 2012 to 2014 for which 17 articles were retrieved, representing $45 \%$ of the total number included in this review. The countries where the respective research was carried are the United Kingdom (five), The United States of America (four), Canada, the Netherlands and Israel (two each) and Spain, Thailand, Mexico and Italy (one each). Regarding the distribution of 
the study localities, it can be seen that, while HIA research is being done worldwide, the concentration of studies is in Europe (15) and North America (14). It should be noted that although no restriction on countries was introduced in the initial search, not one Brazilian study was retrieved for the period the review focused on.

Table 1 below displays the 38 references selected according to the study objective and criteria, identifying the year of publication, country, authors and study objectives.

Table 1 - Publications addressing Health Impact Assessment and its association with the theme 'Environment', by year, country of research execution, authors and study objective, obtained from the CAPES Periodicals Portal in August 2017.

\begin{tabular}{|c|c|c|}
\hline $\begin{array}{l}\text { Year / Study } \\
\text { Country }\end{array}$ & Authors & Objective \\
\hline $\begin{array}{c}2017 / \\
\text { Zimbabwe }\end{array}$ & DALU, M. T. B. et al. & \\
\hline 2017 / Italy & LINZALONE, N. et al. & $\begin{array}{l}\text { Describe the democratic trajectory and results of a } \\
\text { Participatory Health Impact Assessment project in } \\
\text { terms of sustainable waste management, Arrezo, } \\
\text { Italy. }\end{array}$ \\
\hline 2016 / India & KUMAR, A. et al. & $\begin{array}{l}\text { Estimate the valuation of health damage } \\
\text { and economic evaluation of health impact due to air } \\
\text { pollution based on the total population of a district } \\
\text { of Mumbai city }\end{array}$ \\
\hline 2016 / USA & $\begin{array}{l}\text { MANSFIELD, T. J.; } \\
\text { GIBSON, J. M. }\end{array}$ & $\begin{array}{l}\text { Develop a survey-based statistical model that } \\
\text { estimates baseline time spent walking and biking } \\
\text { as a function of the type of transportation used to } \\
\text { commute to work along with demographic and built } \\
\text { environment variables using routine data from } \\
\text { the } 2009 \text { US National Household Travel Survey } \\
\text { and validate the model using survey data from the } \\
\text { Raleigh metropolitan region, NC, USA. }\end{array}$ \\
\hline 2016 / Spain & SERRANO, E. et al. & $\begin{array}{l}\text { Analyze impacts attributable to a new fish market } \\
\text { and delays in the regeneration of a poor area in a } \\
\text { deteriorated region of the Pasaia Bay, Spain. }\end{array}$ \\
\hline $\begin{array}{c}2015 \text { / } \\
\text { Switzerland }\end{array}$ & PEREZ, L. et al. & $\begin{array}{l}\text { Assess health impacts associated to climate change } \\
\text { policies related to local transportation in Basel, } \\
\text { Switzerland. }\end{array}$ \\
\hline 2015 / USA & $\begin{array}{c}\text { KORFMACHER, K. S. } \\
\text { et al. }\end{array}$ & $\begin{array}{l}\text { Analyze cases, common themes, and lessons learned } \\
\text { for the future practice of HIA in the waterfront zone } \\
\text { and beyond. }\end{array}$ \\
\hline 2015 / USA & SCHUCHTER, J. et al. & $\begin{array}{l}\text { Describe the experiences and long-term results } \\
\text { obtained with HIA trainees in the USA to reveal } \\
\text { opportunities for improving their capacity building } \\
\text { activities and their HIA practices. }\end{array}$ \\
\hline
\end{tabular}




\begin{tabular}{|c|c|c|}
\hline 2014 / UK & $\begin{array}{l}\text { MESA-FRIAS, M.; } \\
\text { CHALABI, Z.; FOSS, } \\
\text { A. }\end{array}$ & $\begin{array}{l}\text { Offer a non-probabilistic alternative for } \\
\text { incorporating uncertainty associated to parameters } \\
\text { due to the imprecision of information, using an } \\
\text { application of the theory of diffuse sets in HIA }\end{array}$ \\
\hline 2014 / Italy & LINZALONE, N. et al. & $\begin{array}{l}\text { Analyze Health Impact Assessment Practices in } \\
\text { Italy to identify key aspects in common in the HIAs } \\
\text { of policies, plans and projects. }\end{array}$ \\
\hline 2014 / Mexico & $\begin{array}{l}\text { RIOJAS-RODRÍGUEZ, } \\
\text { H. et al. }\end{array}$ & $\begin{array}{l}\text { Carryout an HIA to document the health benefits } \\
\text { obtained in various } \mathrm{PM}_{10} \text { and } \mathrm{O}_{3} \text { reduction scenarios } \\
\text { in the air of the Mexico City Metropolitan Area. }\end{array}$ \\
\hline 2014 / UK & $\begin{array}{l}\text { CHALABI, } \mathrm{Z} . \\
\text { KOVATS, S. }\end{array}$ & $\begin{array}{l}\text { Describe a new method for evaluating adaptation } \\
\text { policies to protect human health providing } \\
\text { complementary analyses and extensions to the work } \\
\text { already undertaken, in anew generic conceptual } \\
\text { structure (MCA4climate) for climate policy } \\
\text { planning. }\end{array}$ \\
\hline 2014 / Global & MORITA, H. et al. & $\begin{array}{l}\text { Evaluate global mortality due to air pollution } \\
\text { stemming from the aviation sector. }\end{array}$ \\
\hline 2014 / Canada & BENUSIC, $\mathrm{M}$. & $\begin{array}{l}\text { Discuss the benefits of mandatory health impact } \\
\text { assessments being proposed in the light of concern } \\
\text { regarding the potential health effects of coal- } \\
\text { transfer installations in the Lower Mainland of } \\
\text { British Columbia. }\end{array}$ \\
\hline 2015 / Canada & ULMER, J. M. & $\begin{array}{l}\text { Provide an overall view of the creation and } \\
\text { development of an empirically based HIA tool and } \\
\text { its application in the city of Toronto. }\end{array}$ \\
\hline $\begin{array}{l}2013 \text { / } \\
\text { Thailand }\end{array}$ & JUNTARAWIJIT, C. & $\begin{array}{l}\text { Examine the health and environmental impacts } \\
\text { associated to a biomass power station in Thailand. }\end{array}$ \\
\hline $\begin{array}{l}2013 / \\
\text { Switzerland }\end{array}$ & WINKLER, M. S. et al. & $\begin{array}{l}\text { Summarize current HIA practice and outline the } \\
\text { potential of HIA to become a critical player with the } \\
\text { major drivers of global change. . }\end{array}$ \\
\hline 2013 / Israel & NEGEV, M. et al. & $\begin{array}{l}\text { Portray the role of social participation in HIA by } \\
\text { means of a multi-cultural approach. }\end{array}$ \\
\hline 2013 / UK & $\begin{array}{l}\text { BOND, A.; CAVE, B.; } \\
\text { BALLANTYNE, R. }\end{array}$ & $\begin{array}{l}\text { Investigate the degree of connection between the } \\
\text { areas of health and spatial planning in specific } \\
\text { geographic regions of the UK: East Anglia and the } \\
\text { West Midlands. }\end{array}$ \\
\hline 2013 / USA & $\begin{array}{l}\text { THORNTON, R. L. J. } \\
\text { et al. }\end{array}$ & $\begin{array}{l}\text { Conduct a multi-stage HIA of the Transform } \\
\text { Baltimore zoning code rewrite based on HIA } \\
\text { practice guidelines. }\end{array}$ \\
\hline 2012 / USA & $\begin{array}{l}\text { HOEHNER, C. M. et } \\
\text { al. }\end{array}$ & $\begin{array}{l}\text { Describe a comprehensive HIA led by an } \\
\text { interdisciplinary academic team with community } \\
\text { partners and discuss unexpected results and lessons } \\
\text { learned. }\end{array}$ \\
\hline
\end{tabular}




\begin{tabular}{|c|c|c|}
\hline 2012 / Spain & $\begin{array}{l}\text { ROJAS-RUEDA, D. } \\
\text { et al. }\end{array}$ & $\begin{array}{l}\text { Estimate the health impacts and benefits of mode } \\
\text { shifts from car to cycling and public transport in the } \\
\text { metropolitan area of Barcelona. }\end{array}$ \\
\hline $\begin{array}{l}2012 \text { / USA, } \\
\text { Israel and UK }\end{array}$ & NEGEV, M. et al. & $\begin{array}{l}\text { Describe and analyze examples of HIA use by } \\
\text { healthcare professionals in three different local } \\
\text { contexts and consider how they affect the integration } \\
\text { of health into environmental policy, planning and } \\
\text { decision-making. }\end{array}$ \\
\hline 2012 / USA & PERDUE, L. A. et al. & $\begin{array}{l}\text { Conduct a rapid HIA to inform the debate within } \\
\text { a state legislature about the value of state policy } \\
\text { and provide information for local planning agencies } \\
\text { to better incorporate health considerations into } \\
\text { planning activities. }\end{array}$ \\
\hline 2012 / UK & $\begin{array}{l}\text { RICHARDSON, J. et } \\
\text { al. }\end{array}$ & $\begin{array}{l}\text { Use an HIA approach to understand the possible } \\
\text { impacts on health and wellbeing of the multiagency } \\
\text { Stepping Stones to Nature (SS2N) project to support } \\
\text { decision makers in altering plans when necessary. }\end{array}$ \\
\hline $\begin{array}{l}2011 / \\
\text { Australia }\end{array}$ & $\begin{array}{l}\text { HORWITZ, P.; } \\
\text { FINLAYSON, C. M. }\end{array}$ & $\begin{array}{l}\text { Serve as a guideline for decision-making that amply } \\
\text { encompasses the interactions among wetlands } \\
\text { ecology, management and human health. }\end{array}$ \\
\hline 2011 / USA & RAJOTTE, B. R. et al. & $\begin{array}{l}\text { Introduce the legal and policy foundations for HIA } \\
\text { under the National Environmental Policy Act } \\
\text { (NEPA) of } 1969 \text { and give additional examples of } \\
\text { HIAs conducted outside the ambit of the NEPA. }\end{array}$ \\
\hline 2010 / Turkey & SOYSAL, A. & $\begin{array}{l}\text { Discuss the emergence of HIA, its practice and } \\
\text { results and investigate whether there is extant } \\
\text { orientation for public healthcare professionals. }\end{array}$ \\
\hline 2009 / USA & $\begin{array}{l}\text { COLLINS, J.; } \\
\text { KOPLAN, J. P. }\end{array}$ & $\begin{array}{l}\text { Discuss the broad applicability of HIA especially in } \\
\text { all US public policies. }\end{array}$ \\
\hline $\begin{array}{l}2009 / \\
\text { Netherlands }\end{array}$ & $\begin{array}{l}\text { SAARLOOS, D.; KIM, } \\
\text { J.; TIMMERMANS, H. }\end{array}$ & $\begin{array}{l}\text { Foster a discussion among researchers and } \\
\text { professionals in the fields of public health and health } \\
\text { promotion on the need to address individual space- } \\
\text { time behavior which is subjacent to the interaction } \\
\text { between built environment and health. }\end{array}$ \\
\hline $\begin{array}{l}2009 / \\
\text { Netherlands }\end{array}$ & $\begin{array}{l}\text { SCHRAM-BIJKERK, } \\
\text { D. et al. }\end{array}$ & $\begin{array}{l}\text { Evaluate the applicability of existing HIA } \\
\text { methodology to quantify the effects of transportation } \\
\text { policies on health at the local level. }\end{array}$ \\
\hline 2008 / UK & $\begin{array}{l}\text { BARTON, H.; } \\
\text { GRANT, M. }\end{array}$ & $\begin{array}{l}\text { Examine whether new construction and } \\
\text { infrastructure are adequately tested for their } \\
\text { health and sustainability credentials so that } \\
\text { environmentally unhealthy aspects that we create } \\
\text { can be progressively transformed. }\end{array}$ \\
\hline
\end{tabular}




\begin{tabular}{|c|c|c|}
\hline 2008 / USA & $\begin{array}{l}\text { BHATIA, R.; } \\
\text { WERNHAM, A. }\end{array}$ & $\begin{array}{l}\text { Examine EIA purposes and procedures, and } \\
\text { existing regulatory requirements in order to analyze } \\
\text { the effects on health and possible obstacles and } \\
\text { opportunities for human health improvement } \\
\text { within the scope of the EIA process citing recent } \\
\text { examples of Integrated Health Impact Assessment } \\
\text { in the federal and state spheres. }\end{array}$ \\
\hline 2007 / UK & ALI, S. et al. & $\begin{array}{l}\text { Conduct a prospective mini health impact assessment } \\
\text { of the 'Towards 2010' program in Sandwell and West } \\
\text { Birmingham in the West Midlands, UK. }\end{array}$ \\
\hline 2007 / USA & CORBURN, J. & $\begin{array}{l}\text { Make a critical review of US urban and public health } \\
\text { planning history and, based on lessons learned from } \\
\text { the review, suggest strategies for reconnecting the } \\
\text { two fields in order to address the challenges of the } \\
21^{\text {st }} \text { century. }\end{array}$ \\
\hline $\begin{array}{c}2005 / \\
\text { Australia } \\
\end{array}$ & NEVILLE, L. et al. & $\begin{array}{l}\begin{array}{l}\text { Describe a prospective Health Impact Assessment of } \\
\text { the Shellharbour Foreshore Management Plan. }\end{array} \\
\end{array}$ \\
\hline 2002 / UK & McCARTHY, M. et al. & $\begin{array}{l}\text { Identify environmental health risk estimates } \\
\text { for industrial and civil developments from the } \\
\text { epidemiological literature and develop and apply } \\
\text { them within a mathematical health impact } \\
\text { assessment model. }\end{array}$ \\
\hline 2001 / UK & KEMM, J. & $\begin{array}{l}\text { Discuss the HIA approach and the requirements } \\
\text { stemming from the advancement of Healthy Public } \\
\text { Policy and their consequences for health policy. }\end{array}$ \\
\hline
\end{tabular}

Source: the authors, 2020.

The thematic categories that emerged from the discussion of the contents of the publications organized by similarities of themes were: 1) HIA practices; 2) HIA and the urban environment; 3) HIA and EIA; and 4) Environment and health.

The studies addressing the first theme, HIA practices, report on the prospective, concurrent and retrospective research conducted in countries in Europe, Asia, Oceania and North and Central America. They present the HIAs of programs (THORNTON et al., 2013), projects (KORFMACHER et al., 2015; LINZALONE et al., 2017; SERRANO et al., 2016; HOEHNER et al., 2012; RICHARDSON et al., 2012) and policies (NEVILLE et al., 2005; SCHRAM-BIJKERK et al., 2009). Regarding the methods used to develop HIAs, the studies identify the use of a method mixing quantitative and qualitative data collection and analysis (THORNTON et al., 2013; SERRANO et al., 2016; HOEHNER et al., 2012); some authors, however, opted for quantitative methods only (JUNTARAWIJIT, 2013; RIOJAS-RODRÍGUEZ et al., 2014; SCHRAM-BIJKERK et al., 2009).

The positive nature of social participation in HIAs is emphasized (LINZALONE et al., 2017; SERRANO et al., 2016; HOEHNER et al., 2012; NEGEV et al., 2013; NEVILLE et al., 2005), as is the multidisciplinary composition of the teams that actually put the HIAs into practice (THORNTON et al., 2013; LINZALONE et al., 2017; SERRANO et al., 2016; HOEHNER et al., 2012; RICHARDSON et al., 2012; NEVILLE et al., 2005). 
One of the main difficulties identified is the division of competencies among the teams executing the HIA which hampers the achievement of consensus (SERRANO et al., 2016). The time needed to carry out an HIA is also considered to be a limiting factor (NEVILLE et al., 2005). A full HIA is considered if inclusive public participation is implemented and the results are reintegrated into the decision-making process. In contrast, quick consultation and engagement can be carried out without the representation of communities, but the decision will be up to a few political actors (LINZALONE et al., 2017; SERRANO et al., 2016). The final report of such assessments is also cited as a difficult challenge insofar as it is necessarily complex but needs to be presented in a form that the public can easily understand (ALI et al., 2007).

The second category, HIA and the urban environment, is made up of studies describing the health impacts of built environments, the transportation sector and air pollution. The studies consider that the practice of relating health planning and spatial planning is very limited; planners acknowledge their lack of in-depth knowledge regarding the association between health and environment, irrespective of whether the latter is planned or not (BOND; CAVE; BALLANTYNE, 2013). The studies show that when healthcare professionals discuss planning in urban environments, they express concern for the geographic location of health service infrastructure in the sense of promoting human health protection but without taking into account the complexity of the healthenvironment association in their planning (BOND; CAVE; BALLANTYNE, 2013).

The results also describe an association between urban transportation and physical activities (MANSFIELD; GIBSON, 2016), showing how the interaction of built environment and health influences human spatial behavior. Interventions in such environments should therefore be directed at improving people's attitudes so that they make healthier choices in their everyday lives (SAARLOOS; KIM; TIMMERMANS, 2009), thereby positively influencing human health by increasing their physical activity levels, preventing sedentariness and obesity and consequently, the epidemic of chronic diseases (ULMER et al., 2015; CORBURN, 2007).

Another category of the analyzed documents is the theme of the association between HIA and EIA. The studies present a discussion of health in the ambit of the EIAs (BARTON; GRANT, 2008; BHATIA; WERNHAM, 2008; BENUSIC, 2014; COLLINS; KOPLAN, 2009; LINZALONE et al., 2014) and the need to get away from the present separation of EIA and HIA and achieve a relationship of holistic integration of health and environment (BARTON; GRANT, 2008, BHATIA; WERNHAM, 2008; LINZALONE et al., 2014).

The practice of EIA without mentioning health aspects appears in some of the studies (BHATIA; WERNHAM, 2008; LINZALONE et al., 2014) which show that on the American, Asian and European continents, EIA is mandatory and supported by the legal framework, whereas HIA is merely optional (BENUSIC, 2014), with no legal provisions in place to ensure its development (SOYSAL, 2010), or with very slow processes of incorporation with specific legislation in course (COLLINS; KOPLAN, 2009). Thus, the studies underscore the need to include the health aspect in all environmental legislation 
and assessments (BHATIA; WERNHAM, 2008).

The Environment and Health category embraces studies that discuss the association between environment and human health and, more specifically, how climate change influences the health of the population at large (PEREZ et al., 2015; CHALABI; KOVATS, 2014). They also discuss the interaction of wetland ecologies and human health (HORWITZ; FINLAYSON, 2011). In this same category, the study of Morita et al. (2014) assessed global mortality due to air pollution and the cost of morbidity associated to air pollution was the study object of Kumar et al. (2016). The latter authors used the air quality monitoring data of the city of Mumbai in India to map air quality and assess the respective health impacts. A single monitoring station represents the quality of the air in a specific locality. The air quality data gathered from the monitoring were spatially interpolated, using various interpolation techniques incorporated in a software program. Subsequently, the Health Impact Assessment was made and the associated health costs estimated based on the exposed population.

\section{Discussion}

The worldwide literature on the association between HIA and the environment, object of the present study, presents and discusses the importance that has come to be attributed to the theme. Although previous HIA studies had been published, it was only in 2001 that the first publication of a study of HIA and the environment appeared. In that year, the International Health Impact Assessment Consortium organized the document known as the Merseyside Guidelines for Health Impact Assessment originally published by the Merseyside Health Impact Assessment Steering Group in Liverpool (SCOTT-SAMUEL; BIRLEY; ARDERN, 2001). The study authors emphasize how the contents of that document give an overall view of the HIA process insofar as it consists of publications of research that was ongoing at the time and stresses how the development and improvement of HIA procedures and methods is necessarily a continuous process.

In the same vein, the studies show that there is no mandatory HIA methodology adopted worldwide but that after 2001 there was a movement seeking to organize the instruments to be used to effectuate that process. Public health institutions, working groups of researchers and professionals, the offices of the World Health Organization and the Pan-American Health Organization in Europe and the Americas (WHO, 2005); (PAHO, 2013) published guides and other documents with similar orientations and methodologies for the practice of HIA based on the Gothenburg Consensus paper of 1999 which declares that democracy, equity, sustainable development, ethics and the use of evidence are the values of HIA (WHO, 1999). The document also describes the main concepts and suggests the stages for unfolding an HIA (WHO, 1999). Like the Merseyside Guidelines, it underscores the importance of distinguishing between procedures and methods for assessing health impacts, conceptualizing procedures as structures for delegating temporary powers and implementing HIA, and methods as systems for carrying them out (SCOTT-SAMUEL; BIRLEY; ARDERN, 2001). 
On the other hand, analyzing the field of knowledge in HIA as being a system composed a theoretical apparat and a structure formed by active institutions and actors, other authors proffer the argument that Health Impact Assessment can be performed using other methodologies than the one publicized by the Gothenburg Consensus (PEREIRA; HACON, 2017).

In regard to HIA practice, it has stages/steps that can vary according to the respective authors and the impacts being assessed. In that sense, scientific method shows itself to be an efficacious tool in the data identification and impact assessment stages. It is the profundity of those stages that will determine the success of the HIA. Capacity building and enhancing knowledge regarding HIA methodology is important to ensure that such assessments are not conducted in a superficial manner (ABE; MIRAGLIA, 2018). Corroborating the Gothenburg Consensus (WHO, 1999), the ethical use of evidence appears as an important HIA value, along with the recommendation of rigor in data management and quantitative and qualitative analyses, based on different scientific disciplines and methodologies to obtain an embracing assessment of the impacts that could be expected. In that perspective, the studies affirm the effectiveness of the mixed method of data gathering and analysis coupled with a multi-disciplinary team to conduct the assessment and they consider social participation to be of fundamental importance for any HIA's success. Social/citizen participation is one of the important practices that HIA promotes and includes in the process (PAHO, 2013).

Regarding the team that conducts an HIA, its composition needs to be multidisciplinary and the reviewed studies provide evidence that the success of an HIA stems from the multi-disciplinary nature of the team responsible for its execution from start to finish, but in a complex way, given that the studies even consider and discuss the limitations that are imposed by the inevitable diversity of opinions interests, qualifications and cultural backgrounds of the individuals that make up the teams. Thus, an important factor for an HIA is that it should include a multi-disciplinary, inter-sector approach, promoting partnerships and sharing among the interested parties, to foresee and assess the impact on health of programs, policies and enterprises (WHO, 2005). Interdisciplinarity should permeate the planning actions in public policy construction for all sectors linked in any way to health and to the environment; that is, the State, civil society, the health system and so on (NOTHAFT; GREGÓRIO; BUSATO, 2018).

In the same vein, the HIA should consider interdisciplinarity as the focus of its performance. It is necessary to articulate various government sectors, society at large and the various disciplines to achieve the construction of transversal inter-sector agendas for the definition re-structuring and implementation of those policies that integrate Health, the Environment and Development (BARBOSA; BARATA; HACON, 2012; PEREIRA; HACON, 2017). To put that articulation into effect and achieve positive results, it is necessary to reflect on and transpose obstacles stemming from the resistance imposed by the inertia of installed situations, the abyss in the relations among the different areas and the difficulty each one has to perceive the others' contributions

One of the consequences of environmental concern provoked by the exhaustion 
of natural resources has been the search for sustainable alternatives and the consequent need to create new techniques and improve current methodologies with a view to drawing man and the environment closer together (HIGUCHI, 2019).

The exhaustion of natural resources is partly due to population increases and the growth of urban centers and that has stimulated the discussion regarding HIA and its association with the urban environment. One of the objectives of HIA, according to the Brazilian Ministry of Health (BRASIL, 2014), is to contribute towards achieving healthy public policies and projects. Furthermore, it is a structured method for determining and ameliorating the health impacts of other sectors so that it can be applied in multiple contexts, such as urban planning, for example. Thus the presupposition of interdisciplinary planning always hovers over the integration of all the sectors involved in an HIA insofar as it is what constructs a pathway for the development of individual disciplinary capacities that fuse together to result in wide embracing planning and actions boosting individual and collective knowledge.

One field of studies on HIA and urban environment evaluates the prospective consequences associated to the construction of highways, cycleways and green areas in large urban centers with a view to stimulating walking and cycling and achieving some reduction in air pollution with the consequent reduction of road transportation. Such actions prove the benefits that accrue to human and environmental health, in addition to reduction in financial impacts stemming from chronic degenerative disease and their associated costs for the public treasury.

According to the World Health Organization (WHO, 2005), HIAs can facilitate the development of planning approaches in an integrated urban environment by bringing together the various sectors to identify potential health impacts and determine interventions to eliminate or minimize their negative effects and maximize any positive ones. That will also help to instill a common understanding of health among the local interested parties (such as politicians, community representatives and professional individuals) and of each sector's responsibility to produce positive results for health. Given that HIA is based on a very broad health model, it takes into account social and environmental aspects and economic and cultural issues and the way they affect the lives of individuals, communities and populations (WHO, 2005).

The gaps that permeate the practice of analyzing Health Impacts in urban planning interfere in the way the thinking on impacts is structured and how the method's limitations are overcome (PEREIRA; HACON, 2017).

The discussion of the HIA and EIA category considers the complexity of the connections between health and environment and sees environmental licensing as partially contemplating the study of health impacts stemming from enterprises or activities that make use of natural resources. However, according to the respective studies, the insertion of health considerations in the EIAs is either non-existent or merely incipient and furthermore it takes place in a disaggregated manner and in disaccord with the World Health Organization recommendation (WHO, 2005) whereby HIA can be done in isolation or inserted in other forms of impact assessment such as Environmental Impact 
Assessment. Health assessment needs to be integrated into the EIA to address public concern, minimize the need for separate assessments for health and environment, demonstrate profitability, minimize adverse effects, maximize health benefits and support the concept of sustainable development (CANADA, 2004).

The fact that not all countries have a legal base for HIA and, also, its dependence on the political powers to institutionalize its integration into EIA are among the important factors that emerged from the studies. According to the World Health Organization, the possibility of incorporating HIA to processes for assessing environmental impacts, integrated impacts or other similar assessments should be considered because it is always advantageous to have new elements in an existing (and sometimes even institutionalized) process. The disadvantage, however, is that the other impact assessment processes fail to highlight health problems (WHO, 2005).

In Brazil the participation of government bodies responsible for health in impact assessments only occurs when they are called on analyze health aspects in environmental licensing processes that require it (BRASIL, 2014), and even then it is limited to specific enterprises and usually associated to the question of malaria in regions where it is endemic. Thus, it makes sense to include health considerations in EIA for social and economic reasons and, ultimately, to guarantee that the health and wellbeing of individuals and society are not jeopardized (CANADA, 2004).

There is a gap in the extant legal framework in regard to aspects of the suffering, health issues, labor issues and the social and cultural relations of populations affected by large-scale ventures. The legal system in force fails to guarantee the rights of such population groups and, furthermore, "[...] making the legislation more flexible, especially in the aspect of environmental licensing, means assuming an even more perverse system that threatens the lives of rural, traditional and indigenous peoples" (GIONGO; MENDES, 2018, p. 434).

When EIA is a practice established by specific legislation then the benefits of incorporating HIA into EIA are considered to be a reduction in costs, guaranteed viability of the practice, and economizing the time that would otherwise be needed to institutionalize the Health Impact Assessment as a separate document.

Among the studies retrieved by this research, the health/environment association was presented in a fragmented way and mainly in the perspective of analyzing risks posed by climate change and environmental pollution. According to Bhatia (2011), environmental effects can include harming health and the biota, interrupting food chains, removing natural resources, transforming natural systems or landscapes, polluting the air, the waters or the soil, and changes in or development of the built environment.

The commonest indirect effects on human health or wellbeing include adverse health effects caused by proximity or exposure to a new or existing environmental risk, including air, water or soil pollution, noise, radiation, biological pathogens, risks of injury, reduction in the quantity or quality of recreational opportunities or of opportunities to access or be in contact with natural areas, or being deprived of the use of culturally important land and natural resources (BHATIA, 2011). 
Thus there is a readily perceptible need for the health sector to present a more effective participation in decision-making processes, "[...] so as to ensure a systemic, interdisciplinary, inter-sector approach to health issues in socio-economic development" (BRASIL, 2014, p. 13).

Rosa et al. $(2018$, p. 10) present the health repercussions stemming from changes in the physical and social environments as being, "hypertension, depression, sadness, listlessness in the face of change and uneasiness in regard to the future".

Actions and reflections associated to an interdisciplinary approach are consolidated and effective in conducting solutions for various kinds of problem related to the assessment of health and environmental factors. It is considered that interdisciplinarity in the integration of health and environment form a suitable matrix for the HIA proposal, given that their purpose is to develop new concepts regarding that association, focusing on more concrete realities as a means to making the implementation of suitable, healthy actions feasible.

\section{Conclusion}

The studies reveal a global advancement of HIAs associated to the environment and they underscore the importance of their being of an inter-sector nature with effective social participation and using mixed data collection methods for data analysis and also, that they should be contemplated in project, program and policy decision-making processes

There is a movement in course to include health considerations in all policies and it defends the integration of HIA and EIAs to boost public health and environment-related decision making processes through the institutionalization of that integration because the EIA already has a consolidated legal basis.

Among the challenges the studies identify are the socialization of the very complex information generated by the HIAs, meaning that the reports should be constructed in a way that enables the populations involved to understand them. They also identify the fragility of urban spatial planning professionals' understanding in regard to health aspects, thereby demonstrating the need for multidisciplinary teams to execute HIAs and all policies and programs that involve any aspect of human health.

HIA is an important process for decision-making and it is necessary to expand scientific knowledge production, discussions and results regarding assessments of the health impacts of ventures/enterprises, public policies and programs arising from economic development processes.

There is, therefore, a patent need to carry out studies and produce publications that represent the concrete results achieved by HIA and to report the experiences of their implementation in different enterprises, policies and programs.

\section{Acknowledgments}


To the Coordination for the Improvement of Higher Education Personnel (Coordenação de Aperfeiçoamento de Pessoal de Nível Superior - CAPES).

\section{References}

ABE, K. C.; MIRAGLIA, S G. Avaliação de Impacto à Saúde (AIS) no Brasil e América Latina: uma ferramenta essencial a projetos, planos e políticas. Interface, vol.22, n.65, pp.349-358, 2018.

ALI, S. et al. A prospective mini health impact assessment of the 'Towards 2010' programme in Sandwell and West Birmingham in the West Midlands. Public Health, Oxford, v. 121, n. 6, p. 469-481, Feb. 2007.

BALBY, C. N. Avaliação de impactos a saúde: desenvolvimento internacional e perspectivas no Brasil. 2012. 158 f. Dissertation (MSc) - Faculdade de Saúde Pública, Universidade de São Paulo, São Paulo, 2012.

BARBOSA, E. M.; BARATA, M. M. L.; HACON, S. S. Desafios e oportunidades para a saúde na gestão socioambiental da indústria de petróleo e energia. Cadernos de Saúde Coletiva, Rio de Janeiro, v. 18, n. 2, p. 315-22, fev. 2012.

BARTON, H.; GRANT, M. Testing time for sustainability and health: striving for inclusive rationality in project appraisal. Journal for the Royal Society for the Promotion of Health, Bristol, v. 128, n. 3, p. 130-139, May 2008.

BENUSIC, M. Mandatory health impact assessments are long overdue. British Columbia Medical Journal, Vancouver, v. 56, n. 5, p. 238-239, June 2014.

BHATIA, R. Health Impact Assessment: a guide for practice. Oakland, CA: Human Impact Partners, 2011.

BHATIA, R.; WERNHAM, A. Integrating human health into environmental impact assessment: an unrealized opportunity for environmental health and justice. Environmental Health Perspectives, Durham, v. 116, n. 8, p. 991-1000, Aug. 2008.

BOND, A.; CAVE, B.; BALLANTYNE, R. Who plans for health improvement? SEA, HIA and the separation of spatial planning and health planning. Environmental Impact Assessment Review, Washington, v. 42, p. 67-73, Sept. 2013.

BRASIL. Ministério da Educação. Coordenação de Aperfeiçoamento de Pessoal de Nível Superior. Portal de Periódicos. Periódicos. 2017. Disponível em: <http://www-periodicos-capes-gov-br.ez224.periodicos.capes.gov.br/index.php?option $=$ com_phome\&Itemid $=68 \&>$. Acesso em: 27 jul. 2017.

BRASIL. Ministério da Saúde. Secretaria de Vigilância em Saúde. Departamento de Vigilância em Saúde Ambiental e Saúde do Trabalhador. Avaliação de Impacto à Saúde - AIS: metodologia adaptada para aplicação no Brasil. Brasília: Editora MS, 2014. 68 p. 
CANADA. Minister of Health. Canadian Handbook on Health Impact Assessment. Ottawa, CA: Minister of Health, 2004. 150 p.

CHALABI, Z.; KOVATS, S. Tools for developing adaptation policy to protect human health. Mitigation and Adaptation Strategies for Global Change, Heidelberg, v. 19, n. 3, p. 309-330, Mar. 2014.

COLLINS, J.; KOPLAN, J. P. Health impact assessment a step toward health in all policies. Journal of the American Medical Association, Chicago, v. 302, n. 3, p. 315-317, Jul. 2009.

CORBURN, J. Reconnecting with our roots: American urban planning and public health in the twenty-first century. Urban Affairs Review, New York, v. 42, n. 5, p. 688-713, May 2007.

DALU, M. T. B. et al. Environmental traps in developing countries: a case of the Dema emergency diesel power plant (EPP), Zimbabwe. Journal of Cleaner Production, Zimbabwe, v. 150, p. 123-126, May 2017.

FLORINDO, A. A. et al. Public Open Spaces and Leisure-Time Walking in Brazilian Adults. International Journal of Environmental Research and Public Health, Basel, v. 14, n. 6, p. $1-12,2017$.

GANONG, L. H. Integrative reviews of nursing. Research in Nursing $\&$ Health, New York, v. 10, n. 1, p. 1-11, Feb. 1987.

GIONGO, C.; MENDES, J. M. R. A legitimação da injustiça social e ambiental: análise da legislação no campo da construção de hidrelétricas no Brasil. Textos $\&$ Contextos, Porto Alegre, v. 17, n. 2, p. 423-436, ago./dez. 2018.

HACON, S. de S. et al. Challenges and Prospects for Integrating the Assessment of Health Impacts in the Licensing Process of Large Capital Project in Brazil. International Journal Of Health Policy And Management, [s.1.], v. 7, n. 10, p.885-888, 30 jun. 2018. International Society for Phytocosmetic Sciences. http://dx.doi.org/10.15171/ijhpm.2018.58.

HIGUCHI, T. A. B.. A EVOLUÇÃO DA AVALIAÇÃO DOS IMPACTOS AMBIENTAIS NO BRASIL E NO MUNDO. 2018. 74 f. TCC (Graduação) - Curso de Curso Superior de Engenharia Ambiental, Universidade Tecnológica Federal do Paraná, Londrina / PR, 2018.

HOEHNER, C. M. et al. Page Avenue health impact assessment: building on diverse partnerships and evidence to promote a healthy community. Health \& Place, Amsterdam, v. 18, p. 85-95, Jan. 2012.

HORWITZ, P.; FINLAYSON, C. M. Wetlands as Settings for Human Health: Incorporating Ecosystem Services and Health Impact Assessment into Water Resource Management. BioScience, Oxford, v. 61, n. 9, p. 678-688, Sept. 2011.

JUNTARAWIJIT, C. Biomass Power Plants and Health Problems Among Nearby Residents: a Case Study in Thailand. International Journal of Occupational Medicine and Environmental Health, Łódź, v. 26, n. 5, p. 813-821, Oct. 2013. 
KEMM, J. Health Impact Assessment: a tool for Healthy Public Policy. Health Promotion International, Łódź, v. 16, n. 1, p. 79-85, Mar. 2001.

KORFMACHER, K. S. et al. Health Impact Assessment of Urban Waterway Decisions. International Journal of Environmental Research and Public Health, Basel, v. 12, n. 1, p. 300-321, Jan. 2015.

KUMAR, A. et al. Air quality mapping using GIS and economic evaluation of health impact for Mumbai City, India. Journal of the Air $\&$ Waste Management Association, Pittsburgh, v. 66, n. 5, p. 470-481, May 2016.

LINZALONE, N. et al. Health Impact Assessment Practice and Potential for Integration within Environmental Impact and Strategic Environmental Assessments in Italy. International Journal of Environmental Research and Public Health, Basel, v. 11, n. 12, p. 12683-12699, Dec. 2014.

LINZALONE, N. et al. Participatory health impact assessment used to support decision- making in waste management planning: a replicable experience from Italy. Waste Management, New York, v. 59, p. 557-566, Jan. 2017.

MANSFIELD, T. J.; GIBSON, J. M. Estimating Active Transportation Behaviors to Support Health Impact Assessment in the United States. Frontiers in Public Health, Lausanne, v. 4, p. 1-18, May 2016.

McCARTHY, M. et al. A health impact assessment model for environmental changes attributable to development projects. Journal of Epidemiology and Community Health, London, v. 56, n. 8, p. 611-616, Aug. 2002.

MENDES, K. dal S.; SILVEIRA, R. C. de C. P.; GALVÃO, C. M.. Revisão integrativa: método de pesquisa para a incorporação de evidências na saúde e na enfermagem. : método de pesquisa para a incorporação de evidências na saúde e na enfermagem. Texto \& Contexto - Enfermagem, [s.1.], v. 17, n. 4, p. 758-764, dez. 2008.

MESA-FRIAS, M.; CHALABI, Z.; FOSS, A. Quantifying uncertainty in health impact assessment: a case-study example on indoor housing ventilation. Environment International, Amsterdam, v. 62, p. 95-103, Jan. 2014.

MINAYO, M. C. S. O desafio do conhecimento: pesquisa qualitativa em saúde. 14. ed. São Paulo: Hucitec; Abrasco, 2015.

MORITA, H. et al. Global Health Impacts of Future Aviation Emissions Under Alternative Control Scenarios. Environmental Science \& Technology, Washington, v. 48, n. 24, p. 14659 14667, Dec. 2014.

NEGEV, M. et al. Integration of health and environment through health impact assessment: Cases from three continents. Environmental Research, New York, v. 114, p. 60-67, Apr. 2012.

NEGEV, M. et al. Stakeholder participation in health impact assessment: a multicultural approach. Environmental Impact Assessment Review, Washington, v. 43, p. 112-120, Nov. 2013. 
NEVILLE, L. et al. A health impact assessment of an environmental management plan: the impacts on physical activity and social cohesion. Health Promotion Journal of Australia, West Perth, v. 16, n. 3, p. 194-200, Dec. 2005.

NOTHAFT, S. C. S.; GREGÓRIO, E. L.; BUSATO, M. A.. Ambiente e saúde: uma reflexão na perspectiva interdisciplinar. In: WINCLER, S.; PEREIRA, R.; TEIXEIRA, M. M.. Cidadania, Socioambientalismo, Atores e Sujeitos Internacionais em Diálogo com o Direito. São Leopoldo: Kariwa, 2018. Cap. 1. p. 45-59.

PAHO - Pan American Health Organization. Health Impact Assessment: Concepts and Guidelines for the Americas. Washington, DC: PAHO, 2013.

PERDUE, L. A. et al. Rapid health impact assessment of policies to reduce vehicle miles traveled in Oregon. Public Health, New York, v. 126, n. 12, p. 1063-1071, Dec. 2012.

PEREIRA, C.; HACON, S. A avaliação de impacto à saúde como campo de saber. Saúde e Sociedade, São Paulo, v. 26, n. 3, p. 829-835, jul./set. 2017.

PEREZ, L. et al. Transport-related measures to mitigate climate change in Basel, Switzerland: a health-effectiveness comparison study. Environment International, Amsterdam, v. 85, p. 111119, Dec. 2015.

RAJOTTE, B. R. et al. Health in All Policies: Addressing the Legal and Policy Foundations of Health Impact Assessment. Journal of Law, Medicine \& Ethics, Boston, v. 39, n. 1, p. 27-29, Mar. 2011.

RICHARDSON, J. et al. Building HIA approaches into strategies for green space use: an example from Plymouth's (UK) Stepping Stones to Nature Project. Health Promotion International, Łódź, v. 28, n. 4, p. 502-511, Dec. 2012.

RIOJAS-RODRÍGUEZ, H. et al. Health impact assessment of decreases in PM10 and ozone concentrations in the Mexico City Metropolitan Area. A basis for a new air quality management program. Salud Pública de México, México, v. 56, n. 6, p. 579-591, Dec. 2014.

ROJAS-RUEDA, D. et al. Replacing car trips by increasing bike and public transport in the greater Barcelona metropolitan area: A health impact assessment study. Environment International, Amsterdam, v. 49, p. 100-109, Nov. 2012.

ROSA, L. et al. Repercussões na saúde das famílias que vivenciaram mudanças ambientais provocadas pela construção de usina hidrelétrica. Ambiente $\mathbb{Q}$ Sociedade, São Paulo, v. 21, p. 1-14, jun. 2018.

SAARLOOS, D.; KIM, J.; TIMMERMANS, H. The Built Environment and Health: Introducing Individual Space-Time Behavior. International Journal of Environmental Research and Public Health, Basel, v. 6, n. 6, p. 1724-1743, Jun. 2009.

SCHRAM-BIJKERK, D. et al. Quantitative health impact assessment of transport policies: two simulations related to speed limit reduction and traffic re-allocation in the Netherlands. Occu- 
pational and Environmental Medicine, London, v. 66, n. 10, p. 691-698, Oct. 2009.

SCHUCHTER, J. et al. Building capacity for Health Impact Assessment: Training outcomes from the United States. Environmental Impact Assessment Review, Washington, v. 50, p. 190-195, Jan. 2015.

SCOTT-SAMUEL, A.; BIRLEY, M.; ARDERN, K. The Merseyside Guidelines for Health Impact Assessment. 2nd. ed. Liverpool: International Health IMPACT Assessment Consortium, 2001.

SERRANO, E. et al. Urban regeneration as population health intervention: a health impact assessment in the Bay of Pasaia (Spain). International Journal for Equity in Health, London, v. 15, n. 145, p. 1-12, 2016.

SOARES, C. B. et al. Integrative review: concepts and methods used in Nursing. Revista da Escola de Enfermagem USP, São Paulo, v. 48, n. 2, p. 335-345, 2014.

SOYSAL, A. Sağlik Etki Değerlendirmesi Nedir? Ne Değildir? TAF Preventive Medicine Bulletin, Turkey, v. 9, n. 6, p. 689-694, 2010.

THORNTON, R. L. J. et al. Achieving a Healthy Zoning Policy in Baltimore: Results of a Health Impact Assessment of the TransForm Baltimore Zoning Code Rewrite. Public Health Reports, Washington, v. 128, n. 3, p. 87-103, Nov. 2013.

ULMER, J. M. et al. Application of an evidence-based tool to evaluate health impacts of changes to the built environment. Canadian Journal of Public Health, Ottawa, v. 106, n. 1, s. 1, p. eS26-eS32, 2015.

WINKLER, M. S. et al. Untapped Potential of Health Impact Assessment. Bulletin of the World Health Organization, Brussels, v. 91, p. 298-305, 2013.

WHO - World Health Organization. Regional Office for Europe. Centre for Urban Health. Health Impact Assessment: Toolkit for Cities. Document 1. Brussels: World Health Organization, 2005.

WHO - World Health Organization. Regional Office for Europe. European Centre for Health Policy. Health impact assessment: main concepts and suggested approach. Brussels: World Health Organization, 1999. 
Simone Cristine dos Santos Nothaft

$\square$ nothaft@hotmail.com.br

ORCiD: https://orcid.org/ 0000-0001-5037-1596
Submitted on: 08/09/2018

Accepted on: 26/06/2020

2020;23:e02112

\section{Nunzia Linzalone}

$\square$ linunzia@ifc.cnr.it

ORCiD: https://orcid.org/ 0000-0002-7289-3122

\section{Maria Assunta Busato}

$\square$ assunta@unochapeco.edu.br

ORCiD: https://orcid.org/ 0000-0003-0043-7037

How to cite: NOTHAFT, SCS.; LINZALONE, L.; BUSATO, MA. Avaliação do Impacto na Saúde e a Relação com o Ambiente: Uma Revisão Integrativa. Ambiente $\mathbb{E}$ Sociedade. São Paulo, v. 23, p. 1-19, 2020. 


\title{
Evaluación del Impactoe en la Salud y su Relación con el Ambiente: Una Revisión Integradora
}

\author{
Simone Cristine dos Santos Nothaft \\ Nunzia Linzalone \\ Maria Assunta Busato
}

São Paulo. Vol. 23, 2020

Artigo Original
Resumo: Identificar e analisar o que está disposto na literatura científica sobre Avaliação de Impacto à Saúde relacionada ao ambiente. Revisão integrativa da literatura com busca de estudos no Portal de Periódicos da Coordenação de Aperfeiçoamento de Pessoal de Nível Superior. Foram incluídos 38 trabalhos. O período com o maior número de publicações foi entre 2012 e 2014, com estudos desenvolvidos principalmente na Europa e América do Norte. As categorias resultantes foram: A prática da Avaliação do Impacto na Saúde; Avaliação do Impacto na Saúde e planejamento urbano; Avaliação do Impacto Ambiental e Avaliação do Impacto na Saúde; Ambiente e Saúde. Há um movimento para a inclusão da Avaliação dos Impactos na Saúde e Avaliação do Impacto Ambiental, com a institucionalização dessa integração tendo em vista que a Avaliação do Impacto Ambiental já tem sua base legal consolidada.

Palavras-chave: Ambiente, planejamento urbano, saúde, Avaliação do Impacto Ambiental.

Como citar: Avaliação do Impacto na Saúde e a Relação com o Ambiente: uma Revisão Integrativa. Ambiente $\mathbb{\&}$ Sociedade. São Paulo, v. 23, p. 1-19, 2020.

DOI: http://dx.doi.org/10.1590/1809-4422asoc20180211r2vu2020L6AO 


\title{
Evaluación del Impactoe en la Salud y su Relación con el Ambiente: Una Revisión Integradora
}

\author{
Simone Cristine dos Santos Nothaft \\ Nunzia Linzalone \\ Maria Assunta Busato
}

São Paulo. Vol. 23, 2020

Artículo original
Resumen: Identificar y analizar el abordaje de la literatura científica sobre la Evaluación del Impacto en la Salud relacionada al tema ambiental. Esta es una revisión integrativa de la literatura con búsqueda de estudios en el Portal de Periódicos de la Coordinación de Perfeccionamiento de Personal de Nivel Superior. Fueron incluidos 38 trabajos. El período con el mayor número de publicaciones fue entre 2012 y 2014, con estudios desarrollados principalmente en Europa y América del Norte. Las categorías fueron: La práctica de la Evaluación del Impacto en la Salud; Evaluación del Impacto en la Salud y planificación urbana; Evaluación del Impacto Ambiental y Evaluación del Impacto en Salud; Ambiente y Salud. Hay un movimiento para la inclisión entre la Evaluación de los Impactos en la Salud y Evaluación del Impacto Ambiental, con la institucionalización de esa integración haya visto que la Evaluación del Impacto Ambiental ya tiene su base legal consolidada.

Palabras-clave: Ambiente; planificación urbana; salud; Evaluación del Impacto Ambiental.

Como citar: NOTHAFT, SCS.; LINZALONE, L.; BUSATO, MA. Evaluación del impacto en la salud y la relación con el medio ambiente: una revisión integradora. Ambiente $\mathbb{\&}$ Sociedade. São Paulo, v. 23, p. $1-19,2020$. 